\title{
Research and Practice on Teaching Reform of Innovation and Entrepreneurship Education
}

\author{
Junjie Zhu \\ School of computer and Information Engineering \\ Central South University of Forestry and Technology \\ Changsha, China \\ Wenke03@163.com
}

\author{
Haoran Liu, Feng Jiang \\ School of computer and Information Engineering \\ Central South University of Forestry and Technology \\ Changsha, China \\ 1032922435@qq.com635286773@qq.com
}

\begin{abstract}
After decades of reform and exploration, higher education has achieved significant experience and achievements in personnel cultivating. Meanwhile, the professional competitiveness of students has also been enhanced rapidly. However, contradiction still remains between universities and enterprises. This subject combines the characteristics of local universities. To explore a way for electronic information specialty, which can meet the demands of regional economy. It conforms by the actual development of local universities students innovative entrepreneurship training model as well, striving to cultivate a large number of innovative ability. Ultimately, it probably provides valid potential protection for the development of information industry in Hunan and the establishment of innovation-oriented country.
\end{abstract}

Keywords-higher education; innovative; entrepreneurship; practice

\section{INTRODUCTION}

Due to years of reform and exploration, higher education has acquired significant achievements in personnel cultivating, teaching modes, students' basic quality, and students' practical ability. Students' employment competitiveness has also been rising swift. However, the contradiction between universities and enterprises still exist. More specifically, it is difficult to find suitable talents for business; graduates can not achieve an ideal job. While advancing the across-the-aboard quality of students, general higher education has developed the model of theoretical and practical teaching. To some extent, it has narrowed the gap between the ability of students and the demand of enterprises, dispelled the employment situation of students and improved employment quality. Nonetheless, it can be shown that the need for innovation does not result only from intensifying competition but also, in a broader sense, includes industrial structure, so as to identify in advance new tendencies in the market place, which aggravated the contradiction between students and enterprises. Therefore, the teaching mode of higher education must accommodate to the prompt development of society, to catch up with the enhancing demand of talents simultaneously. Currently, the population of college graduates will reach at 7.65 million, which is the largest number in recent years. Their employment is closely related to the benefit for thousands of families. Furthermore, it is bound up with the economic construction, social stability, confidence and enthusiasm of the whole

Research on the Construction of the Application-Oriented Person with Ability in Electronic Engineering(NO:201300185)

Research and Exploration on the Teaching Reform of the Innovative and Pioneering Education of Electronic Information Specialty in Hunan society for higher education. As a result, it is a major issue for higher education to foster students entrepreneurial awareness, improving their innovative spirit, and enhance students' creativity. Moreover, it is an effective method to improve the employment competitiveness.

The CPC Central Committee Political Bureau Standing Committee, Premier Li Keqiang delivered an important instructions in the first Chinese "Internet +" College Students Innovation and Entrepreneurship Competition Finals(October, 2015). He pointed out that students are the driving force to implement innovation development strategy and public entrepreneurship. It is essential for them to earnestly study and master more knowledge. Students ought to participate the innovation entrepreneurship to improve practical ability at the same time. To provide a steady stream of talent support for the innovative country construction, the education sector and the broad masses of educators must take some measures to execute the national policy-making arrangements and actively carry out the reform of teaching and exploration. In addition to this perspective, it will be shown that enhancing students' entrepreneurial awareness and innovation ability is an increasingly essential factor towards the personnel successful. Meanwhile, Liu Yandong, member of the Political Bureau of the CPC Central Committee and vice premier of the State Council, emphasized that university probably enhance the sense of responsibility, to promote the innovation and entrepreneurship education reform, comprehensively improve the quality of personnel training, and provide effective personnel support to build an innovation-oriented country. What's more, Zhu Daohong, member of the CPPCC and vicepresident of the Central South University of Forestry and Technology, illustrated that universities should adopt various means to promote innovative education. He believes talent is the key to boost public entrepreneurship and people innovation. One of the main measures of talent cultivation is higher education. Formerly, our education methods were more inclined to explain knowledge. However, we need to rising the cultivation of students' innovative spirit and ability nowadays. Higher education should include innovation and entrepreneurship, bring some exploratory and discussion courses. Students should learn theoretical knowledge in the classroom, also practice skills outside the classroom.

The Ministry of Education issued "on the 2016 session of the National General College graduates employment notice". 
It required universities to arrange the 2016 graduates employment work properly(December, 2015). The notice demonstrates universities should set up innovation and entrepreneurship courses in 2016. Universities should assimilate innovation entrepreneurship education into the talent cultivation program, associated with enhancement students' entrepreneurial awareness, innovation spirit and creativity in various ways, which as an important practical way to implement the national cultivation of high quality applied talents. It is also in line with Chinese popular higher education needs, and a way suitable for local institutions of higher development. In view of this condition, this subject tries to explore a method, which can meet the requirements of regional economy. The way conforms to the actual development of local universities innovative entrepreneurship training model, striving to cultivate a large number of innovative students. Eventually, to provide strong talent support for the development of information industry in Hunan and the innovation-oriented country establishment.

Innovation and entrepreneurship education in foreign has more than half a century of history. For instance, the United States Harvard Business School set up business courses from 1947. Meanwhile, innovation and entrepreneurship education were driven by the United States and other countries since the 1980 s, as well as UNESCO and other international organizations. It has become a worldwide trend of education reform. In foreign, innovation entrepreneurship education is two interrelated but clearly diverse concept. The United Kingdom, France, and other countries attach great importance to the primary school stage entrepreneurship education. They pay more attention to develop students' leadership, communication skills, business and economic awareness from childhood. Undeniably, there do exist a need for China to carry out innovation entrepreneurship education systematic in universities. Education sector should make innovation entrepreneurship education run through all kinds of education institution in different levels and types university[1].

The public regards innovation as the foundation and core of entrepreneurship, and put forward the concept of innovation and entrepreneurship education in China. In recent years, Chinese innovation and entrepreneurship education development is relatively rapid, which is becoming a crucial direction of Chinese education reform and trends. Firstly, the training mode of domestic innovative entrepreneurship education can be divided into two stages in terms of the time development process. The first stage is entrepreneurship education. The landmark document is promulgated in January 1999, "21st Century Education Revitalization Plan." It emphasized the importance to strengthen the entrepreneurial education of teachers and students, university may set up hightech enterprises, which indicate that Chinese higher education has entered the entrepreneurial education-driven talent training model research stage. It was developed vigorous in the period from 1999 to 2009. The second stage is the innovation and entrepreneurship education-driven. The landmark document is issued in 2010, "vigorously promote the innovation and entrepreneurship education in universities and independent entrepreneurship." It emphasized the innovation entrepreneurship education, which symbolizes the entrepreneurial education-driven talent training model has been transferred into a new stage of development. Secondly, the training mode of domestic innovation entrepreneurship education can be classified into two types: the training mode of innovation entrepreneurship education in the key universities and in local institutions of higher education. Thirdly, there are four types of innovative entrepreneurship training models: experimental zone construction, project incubation, academic competition and school-enterprise cooperation[2].

Recently, due to a large amount of effective attempts and exploration in education personnel training mode, local universities has made dramatic achievements. Guilin University of Electronic Science and Technology of China, as a local university for engineering talents, launching in-depth university characteristics innovative practice education. The university focuses on the reform of curriculum teaching, to establish practical platform as the core and build the service guarantee system as the key matter. The school has mainly completed the following works: to integrate the teaching resources of university, enterprises and society, and realized the organic combination of in-class and extracurricular, theory and practice, inside and outside the school. Furthermore, the school bring about the innovation entrepreneurship education system that named three levels, four platforms and four guarantees[3]. Hunan University of Science and Technology employ the deepening of teaching content, enrich the teaching methods and update the curriculum system, to achieve optimization of innovation talents training model which is suitable for undergraduate level. This model includes the following five requirements: the combination of the characteristics of the school and the professional, the society demands, to build a scientific training model, the application of innovation ability of students training throughout the whole process, to emphasize the theoretical knowledge explain and the application of capacity training equally important, especially the cultivation of innovation ability [4]; In view of the present situation of innovation entrepreneurship talents, Guangxi University for Nationalities analyzes the basic quality of the students. In order to solve the employment problem of college students, it constructs the curriculum system of college students' innovation entrepreneurship education and implements the scheme of college students' innovation and entrepreneurship training plan[5]; Chongqing University of Technology adopt the strengthening of electronic information engineering professional talents ability training, to boost up the students' ability in many regards. In order to cultivate electronic information engineering professional application talents, the university performs a series of teaching reform and exploration. It constructed the personnel training mode, according to the class enrollment and 211 section training and broke the traditional professional boundaries; the combination of basic platform and professional module teaching system has been built and implemented. Based on that, the teaching system of the theory curriculum can be optimized, and the trend of individuation has been adapted as well. To integrate the personnel training and practical ability into practice system. Finally, structure a multilevel and category practice teaching system. The training mode was based on the training program, which supplemented by the practical ability training program. 
It solves the problem how to connect the theoretical and practical courses in education. To ensure that the students' multidimensional ability be synchronized upgrade[6]. The South China University of Technology explores the aspects of teaching plan, curriculum system, student project, differentiated teaching, school-enterprise cooperation and so on, and practice in the aspect of learning, the students' interests, atmosphere, competitive platform, research team, independent entrepreneurship. In brief, innovation and entrepreneurship education play a positive role in the practice of electrical and electronic reform[7].

The Technology Electronic Information Engineering of Central South University of Forestry was established in 1995, with a history of 21 years. In the course of its establishment, it has established computer science, technology, automation, communication engineering, software engineering, and other electronic information interrelated professional. In terms of talent training mode, the students' innovate and practical ability has obtained a wealth of experience in teaching reform. Under the current background of mass innovation, electronic information professional innovation entrepreneurship education and teaching reform will improve the employment competitiveness of students. It will be a useful attempt to grope for a new model. Moreover, it can entirely improve the quality of personnel training, to provide strong talent support for the construction of innovative country.

\section{RESEARCH AND REFORM OBJECTIVES}

The project is based on the provincial practice platform of "Hunan University of Electronic Information Innovation Training Center". The guidance is the reform results of the subject "Electronic Information Engineering Excellence in Applied Talents Training System Construction Research". The concept of innovation entrepreneurship education penetrate the electronic information personnel training program, for the sake of form a innovation and entrepreneurial characteristics professional training system; This subject intensify the platform of practical teaching, and build an electronic professional training platform, which possess the feature of inspire and cultivate students' sense of pioneering, innovation and creativity. The research method laid stress on that problem-based learning, project-based learning and case-based learning, emphasizing the curriculum system design with strong practicality, novel form and students' interest. Meanwhile, by means of fortified the cooperation between schools and enterprises, to build electronic information professional multilevel and diversified training mode; all the major university put a high value on the construction of highquality teaching staff. The construction and implementation of this project will host the students ability of innovation and entrepreneurship. It will supply for more needed innovative talents for the development of information industry in Hunan, also a major project for other universities in Hunan to carry out innovative entrepreneurial personnel training.

\section{SPECIFIC RESEARCH CONTENT}

\section{A. Curriculum Development Program}

The innovation and entrepreneurship education curriculum embedded in electronic information personnel training program. There are three aspects of curriculum design: how to cultivate students' awareness of entrepreneurship, how to improve student innovation, how to enhance the creative ability of students. The innovation entrepreneurship teaching and training system, perfect and practical electronic information professional were probably developed after 3 to 4 years of student training. In the personnel training program, university should set a series courses of innovation entrepreneurship, it is necessary to regard the education curriculum as compulsory or elective courses. On the basis of original training program, the program should increase career planning series and innovation, entrepreneurial operation series of courses.

\section{B. Construction and Optimization of Practice Platform}

On the basis of the existing practice platform, university should create innovative entrepreneurial characteristics practice platform for the electronic information, and elevates pupil innovation entrepreneurship training. Through a large number of practical training, students are most likely to possess creative inspiration. In other words, the inspiration can be achieved when students possess a solid hands-on ability. When the inspiration of innovation was designed into practical application product, it gradually formed sense of entrepreneurial and foundation of entrepreneurial. Therefore, the improvement of college students' innovate ability depends on the cultivation of students' practical ability. The cultivation of students' practical ability relies on how to build a high level of teacher guidance, management science and norms practice platform.

\section{Curriculum System Adjustment}

The university should cooperate with the innovation and practice teaching platform construction, to adjust the course system, to reform the teaching contents and teaching methods, to promote the research-based learning methods such as problem-based learning, project-based learning and case-based learning. At the same time, the curriculum system design emphasizes the strong practice, the novel form, which the student is interested. To strengthens the student innovation entrepreneurial ability training.

\section{School-enterprise Cooperation}

In order to provide the opportunity that directly contact with the design process of enterprise products and demands for students, university should strengthen cooperation with enterprises. Thereby, it makes the gap between the needs of employers and students' ability get smaller. Finally, the improvement of the students' core competitiveness can be reached. Multilevel and diversified school-enterprise cooperation refers to the school and enterprise mutual penetration. Which the oriented is business needs, the goal is the addition of students' ability. 


\section{E. Construction of Teaching Staff}

The import of electronic business innovation staff is an equally critical element for university. Simultaneously, the existing innovation entrepreneurship training and evaluation were supposed to augment. To put their effort into build a high-quality, strong sense of responsibility teaching staff. To cultivating innovative talents of electronic information class lies in the construction of teaching staff is that really count. In other words, teachers must have a certain project experience or career planning guidance. Full-time teachers should have practical experience in engineering, some of them must observe years of work experience. Therefore, schools and colleges need to increase the introduction of high-quality teachers. It is urgent to reform the current teaching staff construction, and target evaluation system. Explore a new faculty construction system, ultimately, to achieve the goal that builds an innovative entrepreneurial talent training teachers staff.

\section{KEY ISSUES TO BE ADDRESSED}

\section{A. Improve the Training Mode and Program}

The university found innovation entrepreneurship foundation and professional courses, gradually, to shape a more scientific and standardized training model program, which suitable for electronic information professional. Training mode, program, standards and objectives should be established to accord with the claim of enterprises, it also keep the pace with the speedy development and transformation of the national economy. In addition, it should be in line with our school personnel training objectives. Learning from the advanced concepts of domestic well known universities, while learn foreign advanced teaching and management experience. Therefore, it is essential to emulate the development rule of engineering practice education from domestic and abroad. Carry out a large number of research literature review and theoretical deduction work to establish the training mode of adaptation, programs, standards and objectives.

\section{B. The Adjustment of Laboratory and Curriculum}

To reinforce the living practice teaching platform and to adjust the laboratory and curriculum this can be good for innovative entrepreneurship of students. Teaching platform as follow: "Hunan University of Electronic Information Innovation Training Center", Hunan Provincial Model Laboratory "Electrical and Electronic Technology Laboratory", and the Ministry of Finance and local laboratories. It has formed a complete teaching platform. Moreover, it is crucial to tinker up the function and plan of the laboratory, in the light of the revised content and the setting of the innovation entrepreneurship training program. Finally, it can serve the construction of the curriculum system better.

\section{Learning Methods and Curriculum System}

A variety of researched is encouraged and guided by Problem-based learning, project-based learning, and casebased learning. To design a curriculum system that has the characteristics of practical, form novel and interest.

\section{Depth School-enterprise Cooperation}

University raises the intensity of cooperation with enterprises, and perhaps makes the partnerships more stable. Central South University of Forestry and Technology have maintained a long-term relationship with the Great Wall Information Company Limited and Jiangsu Lvyang electronic Company Limited. The two company also as excellent practice base in Hunan Province. It is the hinge for innovation entrepreneurship talent plan to establish friendly relationship with enterprise. In recent years, due to the solid professional skills, enterprise thinks highly of our graduates. The graduates also have a certain impact in community. Most of them become the backbone of enterprises and technical backbone. Hence, how to strengthen the cooperation with excellent graduates is the ideal way and method to realize innovation entrepreneurship training.

\section{E. Improve the Teaching Staff}

The first problem is the introduction of Innovation entrepreneurship talent; the second one is how to consolidate the existing training mode and evaluation mechanism of innovation entrepreneurship. University might take the import of high-quality innovative entrepreneurship personnel seriously. They must not only give a guarantee in the treatment and institution, but also give humanities care to the teachers. In addition, university should attach importance to the existing innovation entrepreneurship training and evaluation mechanism. Through the incentive policies to release the passion of teachers, pledge better cultivation of innovative entrepreneurial talent.

\section{CONCLUSION}

Innovation entrepreneurship education has become a worldwide trend of education reform. This paper proposed that combine innovation entrepreneurship education with personnel training. The education department should make efforts to build an innovation training system for electronic information specialty, to constructing an entrepreneurship training platform for students, and to heighten cooperation between schools and enterprises. University ought to attach great importance to the construction of high quality teachers staff. Moreover, the construction and implementation of this project will promote the students ability construction of innovation and entrepreneurship. It will supply for more required innovative talents for the development of information industry in Hunan, also a major project for other universities in Hunan to carry out innovative entrepreneurial personnel training and accumulated valuable experience.

\section{ACKNOWLEDGMENT}

This work is supported by Research and Exploration on the Teaching Reform of the Innovative and Pioneering Education of Electronic Information Specialty in Hunan. Research on the teaching reform of higher education in Hunan: Research on the Construction of the Application-Oriented Person with Ability in Electronic Engineering(NO:201300185) also support this work. 


\section{REFERENCES}

[1] Innovation and entrepreneurship education focuses on cultivating the spirit of innovation and entrepreneurial ability. People's daily, 2015

[2] LIU Zhi-Kan, ZHAO Feng, ZHANG Zhi-wei. Study on the Mode of Cultivating Innovative and Enterprising Talents in Electronic Information Specialty in Local Universities: Current Situation, Problems and Prospects [J], Higher Education Forum, 2016 (1).(in Chinese)

[3] Wei Yinxia,Huang Ke, Guo Qing. Local university of engineering innovation and entrepreneurship education system research and practice [J], Experimental Technology and Management, 2015 (2).(in Chinese)

[4] Wu Xiaofeng, Tang Zhijun, Xi Zaifang, etc .. Electronic information professional innovative talents training model [J], Contemporary Educational Theory and Practice, 2015 (7).(in Chinese)

[5] Lu Zhenkun, Ye Haiyan. Based on the model of gradual and orderly development of students' ability of innovation and entrepreneurship [J], University of Education, 2015 (8).(in Chinese)
[6] Zhao Mingfu, Luo Binbin, Hu Xinyu, et al. Exploration and Practice of Cultivating Advanced Applied Talents in Electronic Information Engineering Specialty $[\mathrm{J}]$, Journal of Wuhan University (Natural Science), 2012 (10).(in Chinese)

[7] Chen Chonghui, deepening innovation and entrepreneurship education to lead the reform of electrical and electronic practical teaching [J], Higher Education Journal, 2016 (4).(in Chinese)

[8] Yan Wei, Yuan Yunsong. Practice and innovation ability of college students to explore and practice [J]. Chinese University Teaching, 2012 (9).(in Chinese)

[9] Huang Linnan, Ding Li structure. Construction of innovation and entrepreneurship education model of exploration [J]. Higher Engineering Education Research, 2010 (6).(in Chinese) 